\title{
An unconditional basic income? How Dutch citizens justify their opinions about a basic income and work conditionality
}

\author{
Federica Rossettia ${ }^{a}$, Femke Roosma $^{\mathrm{b}}$, Tijs Laenen ${ }^{\mathrm{a}}$, Koen Abts ${ }^{\mathrm{b}}$
}

Accepted for publication in Journal of International and Comparative Social Policy

\begin{abstract}
The article focuses on one of the core but controversial features of a universal basic income (UBI): its unconditionality. Using qualitative in-depth interviews collected in the Dutch municipality of Tilburg in 2018-19, we examine the arguments underlying popular opinions about a UBI and work conditionality. The analysis suggests that these arguments can be interpreted from two theoretical perspectives. On the one hand, respondents make frequent use of deservingness criteria referring to the characteristics of welfare recipients, such as their need and work willingness. On the other hand, they justify their opinions using arguments related to the characteristics of welfare schemes, such as their administrative and financial feasibility. Our findings offer important insights concerning political actors who support (or oppose) the real-world implementation of a UBI.
\end{abstract}

Keywords: basic income, work conditionality, public opinion, in-depth interviews, the Netherlands

${ }^{a}$ Centre for Sociological Research, KU Leuven, Leuven, Belgium; ${ }^{b}$ School of Behavioral and Social Sciences, Tilburg University, Tilburg, The Netherlands.

*Corresponding author. Email: federica.rossetti@kuleuven.be 


\section{Introduction}

In recent decades, there has been growing interest in the old idea of a universal basic income (UBI). The idea of a guaranteed minimum income for all citizens, without having to do anything in return, has fascinated scientists and political philosophers for many years, but in the aftermath of the financial crisis of 2008 it has entered the public debate again and is increasingly being considered as a serious policy proposal (OECD, 2017). The current article focuses on one of the defining features setting a UBI apart from most existing social security systems: its unconditionality (van Parijs, 2004). The fact that a UBI would not be conditional on work-related requirements directly opposes the trend of increasing conditionality that has characterized European social policy over the past decades (Knotz, 2018). Whereas social rights were central in the design of social provisions during the golden era of the welfare state, nowadays welfare benefits - in particular unemployment and social assistance benefits - have become much more conditional on the fulfilment of work-related obligations; a trend that seems to count on high public support across Europe (Buss, 2018; Fossati, 2018).

Our country case, the Netherlands, is no exception (perhaps even a frontrunner) in this regard: imposing work obligations on welfare recipients has been central to the 'welfare-to-work' strategy of successive Dutch governments and has become a widely implemented and well-supported policy paradigm (Hoogenboom, 2011). This culminated in 2015 with the introduction of the Participation Act, enabling municipalities to implement the so-called Tegenprestatie: a workfare-oriented instrument that forces social assistance recipients to perform unpaid activities in return for the benefits they receive. At the same time, however, the Netherlands has a long history of lively public debate about a UBI, spurred not only by a handful of passionate activists (as in many other countries), but also by established governmental organizations and political parties (Groot $\&$ van der Veen, 2000). Nevertheless, for various reasons, a UBI has never actually been implemented as a radical alternative to the Dutch welfare state (Vanderborght, 2004). Most recently, some municipalities have initiated what are termed 'trust experiments', which relieve social assistance recipients from all work-related duties (Groot, Muffels, \& Verlaat, 2019). Because these municipal experiments are unconditional, as a UBI would be, they are often also called 'basic income experiments', even though they are restricted to the recipients of means-tested social assistance (van der Veen, 2019; Widerquist, 2018). As a result, the Netherlands has become the scene of a fierce clash between two 
social policy measures that are diametrically opposed in terms of work conditionality: the workfare-based Tegenprestatie and the UBI-inspired trust experiments. This makes the Dutch case a particularly interesting context for an in-depth investigation into the social legitimacy of a UBI and work conditionality. ${ }^{1}$

Evidence from quantitative surveys conducted in the Netherlands since the beginning of the 1990s shows that support for work conditionality has remained high and fairly stable across time, while support for a UBI seems to have fluctuated (see Appendix 1). However, most existing surveys tell us little about the types of arguments people spontaneously use to support (or oppose) a UBI and work conditionality, and such knowledge is important for political actors trying to build (or erode) public support for concrete policy proposals. To overcome this issue, the current article makes use of qualitative in-depth interviews in order to examine the arguments underlying popular opinions about a UBI and work conditionality. The 49 semi-structured interviews were carried out in the city of Tilburg, one of the municipalities that have initiated a trust experiment. This makes Tilburg a unique context to enhance our understanding of people's underlying reasoning about a guaranteed basic income and the (un)conditionality of benefits.

In the remainder of the article, we start by giving an overview of the Dutch income benefits system and of the studies on the social legitimacy of a UBI and welfare conditionality among the Dutch population. We then introduce our data and methods, followed by the results of our inductive analysis that reveal the main argumentations respondents used to justify their opinions about a UBI and the Tegenprestatie. The last section concludes and discusses the empirical findings of our analysis, which show that the arguments used can be interpreted from two perspectives: on the one hand, deservingness theory - an approach that is used in welfare attitudes research to distinguish criteria that people apply to evaluate whether or not welfare recipients are deserving of benefits (van Oorschot, Roosma, Meuleman, \& Reeskens, 2017). On the other hand, arguments that relate to the feasibility of welfare schemes.

\section{Basic income and work conditionality in the Dutch income benefits system}

With regard to the fulfilment of work-related obligations, all income benefit schemes can be located on a wide-ranging continuum (see Figure 1). At one extreme, there are income 
benefits that are granted as an unconditional and inalienable social right, completely relieving recipients of the duty to engage in work-related activities. The prototypical example of such a 'no-strings-attached approach' is a UBI, often defined as 'an income paid by a political community to all its members on an individual basis, without means test or work requirement' (van Parijs, 2004, p. 8). At the other extreme, we find income benefits paid on the strict condition that people work in return for the money they receive. Such workfare schemes typically make people 'an offer they can't refuse' (Lodemel \& Trickey, 2001), by severely punishing recipients with benefit cuts (or even full withdrawal) if they do not comply with the work requirements imposed on them, which often consist of demeaning types of community service (e.g. public road litter collection). In between the two extremes of the continuum, there are many other types of income benefit schemes. An example closer to the right-hand end of the scale is what Groot and van der Veen (2000, p. 19) term 'conditional welfare'. These income benefits are conditional on the fulfilment of some work-related obligations, such as job-seeking and training, but allow the recipients some leeway in choosing a job that suits their educational, occupational and geographical background. An example closer to the lefthand end side of the continuum is Atkinson's (1996) much-discussed participation income, a type of basic income that is granted to all citizens on the condition that they engage in labour or other socially appreciated activities, such as caregiving, studying or volunteering.

Figure 1. Income benefit schemes on the continuum of work conditionality.

WORK CONDITIONALITY

\begin{tabular}{lllllll} 
Low & & High \\
\hline $\begin{array}{l}\text { Unconditional } \\
\text { basic income }\end{array}$ & $\ldots$ & $\begin{array}{l}\text { Participation } \\
\text { income }\end{array}$ & $\ldots$ & $\begin{array}{l}\text { Conditional } \\
\text { welfare }\end{array}$ & $\ldots$ & Workfare
\end{tabular}

Based on: Groot \& van der Veen (2000)

Where does the Dutch income benefits system lie on this continuum of work conditionality? In the Netherlands, the idea of a UBI has been on the political agenda 
from as early as the mid-1970s, and has subsequently waxed and waned depending on the state of the economy, the level of unemployment and developments in social policy (Groot \& van der Veen, 2000; Vanderborght, 2004). What sets the Netherlands apart from many other countries is that a (partial) basic income has not only been discussed by a few die-hard activists (usually scientists or politicians who are so convinced by the idea of a UBI that they disregard its administrative and financial feasibility), but has also been examined closely on multiple occasions in official reports issued by established governmental agencies. ${ }^{2}$ Nevertheless, a UBI has never garnered sufficient political support to be actually implemented. Although the reasons for this are plentiful, most observers agree that 'the radical unconditionality of basic income with regard to work requirements constitutes the feature that most contributes to making it impossible to sell' (Vanderborght, 2004, p. 31). This is especially true in the Dutch context, where a strong work ethos prevails, and where both citizens and politicians seem to loathe the idea of giving 'free money' to 'free riders' (Groot \& van der Veen, 2000). Therefore, a UBI has never gone beyond the stage of public debate in the Netherlands.

Work conditionality, by contrast, has increasingly been an object of public policy. In light of the 'activation turn' (Bonoli, 2010) or 'conditionality turn' (Watts \& Fitzpatrick, 2018), the Netherlands has moved considerably closer to the right-hand end of the work conditionality scale. The Dutch income benefits system - particularly unemployment insurance, social assistance and disability benefits - has become much more conditional over recent decades (Bruttel \& Sol, 2006; Hoogenboom, 2011; Laenen \& Larsen, 2018; van Oorschot \& Engelfriet, 1999). The ongoing trend towards increased work conditionality culminated in 2015 with the introduction of the Participation Act, which gave municipalities the legal competence to implement a workfare-oriented instrument - the Tegenprestatie - in local social assistance. In practice, social assistance recipients are now obliged to perform unpaid, socially useful activities in return for the benefits they receive, if their municipality requires them to do so. The political logic behind such a workfare policy is based on the quid pro quo principle: it is considered only fair that welfare recipients are required to 'return the favour'.

Following the trend towards increased conditionality, the Netherlands has seen a revival of the UBI debate, mainly fuelled by Rutger Bregman's high-impact book (Free money for everyone ${ }^{3}$ published in 2014), in which a UBI is proposed as a radical and utopian alternative for a better society. Inspired by the revival of the UBI concept and as a reaction to the strictness of the Tegenprestatie, a number of Dutch cities started to use 
the possibilities offered by the Participation Act to experiment with policy instruments doing the exact opposite; that is, freeing social assistance recipients from work-related duties. These municipalities implemented so-called 'trust experiments', with the explicit aim to study their effects on recipients' labour market participation, health and well-being (Groot, Muffels, \& Verlaat, 2019; van der Veen, 2019; Widerquist, 2018). The main idea behind these experiments is that trusting people is a much stronger stimulus to (re)integrate welfare recipients (and citizens more generally) into the broader society than the enforcement of reciprocal work duties. Although these municipal experiments are restricted to the recipients of means-tested social assistance, it is argued that they are the closest real-world approximation of a basic income scheme in the Netherlands, because they grant fully unconditional benefits to able-bodied people, irrespective of their work willingness (Groot et al., 2019; van der Veen, 2019). ${ }^{4}$ Further, a trust experiment was recently initiated in the city of Tilburg, where we carried out our in-depth interviews.

\section{Basic income and work conditionality in Dutch public opinion}

It is often argued that public opinion has blocked the implementation of a UBI in the Netherlands, acting to veto welfare reforms in this direction. However, with the exception of a few occasional surveys during the last decades (see Appendix 1 for an overview), relatively little is known about the social legitimacy of a UBI among the Dutch population. In 1993, a survey on public support for radical social security reforms conducted by the Social and Cultural Planning Bureau (SCP) revealed that only 19 per cent of the respondents were in favour of a move towards a partial basic income scheme (Vrooman \& De Kemp, 1995). A few years later, the Welfare Opinions Survey (WOS) revealed a similar proportion of people in agreement with the proposal of a full UBI (van Oorschot, 1998). In the 2001 Eurobarometer, support in the Dutch population for a UBI seemed to have increased to 70 per cent, to then drop again to 47.3 per cent in 2016 with the last public opinion data available from the European Social Survey (ESS). Such contrasting findings reveal that it is difficult to forecast what proportion of the electorate would support the implementation of a UBI scheme and why.

In contrast with the unknowns concerning the social legitimacy of a UBI, support for making income benefits conditional on the fulfilment of work-related obligations has been remarkably stable in the Netherlands. Data from the early 1990s show that more than half of the Dutch population supported the implementation of a fully-fledged 
workfare scheme (van Oorschot, 1998). Further, in the 2001 Eurobarometer, no fewer than 81.7 per cent of the Dutch sample were in (slight or strong) agreement with the idea that the unemployed should be forced to take a job quickly. In the $2016 \mathrm{ESS}$, respondents were asked to indicate what should happen to a person's unemployment benefit if he or she turns down a job because it pays a lot less than their previous work. A minority (17.3 per cent) responded that the unemployed should keep all the benefits, while the rest were in favour of reducing the benefits (albeit to different extents). It thus seems that there is a broad support base in the Netherlands for imposing work obligations on welfare recipients, reflecting the strong work ethic of its population (see also Houtman, 1997; Laenen \& Larsen, 2018; Roosma \& Jeene, 2017).

The evidence from quantitative surveys provides us with a first impression of how a UBI and work conditionality (concretely implemented for example in the Tegenprestatie scheme) could be supported among the Dutch public. However, the available surveys provide little information on what type of arguments underlie people's relevant opinions. A notable exception in this regard is the WOS of 1995, in which respondents were asked to choose between a number of arguments to justify their opinions in favour of or against a UBI and workfare (see van Oorschot, 1998). The answer categories revolved around three major topics: work ethic, the economic consequences of the policies and the deservingness of the recipients. For the first, one example was that if a UBI were to be implemented, 'the incentive to do paid work will become too low'. One of the work ethic arguments in favour of workfare was that "presently too many people obtain a benefit while they could work if they wanted to'. An example of a deservingnessrelated reason for not implementing a UBI was that 'the basic income will also be given to people who do not need it at all'. To justify support for workfare, one of the deservingness arguments was 'it is $\mathrm{OK}$ if government demands something in return for a benefit'. With regard to the economic consequences, an argument for the opponents of a UBI was 'it would be too costly', while workfare opponents could argue that 'it will invoke false competition with regular jobs'. The Dutch seemed to largely opt for arguments related to deservingness and the work ethic, both in the case of opposition to a UBI and in support for a workfare scheme. However, these arguments only partially captured people's motivations, since they were predefined by the researchers. What is still needed is a 'bottom-up' approach, which would allow us to identify the arguments people freely use to justify their welfare opinions (Laenen, Rossetti, \& van Oorschot, 2019). 


\section{Data and methods}

To examine how Dutch citizens feel about a UBI and work conditionality, our qualitative study is based on 49 semi-structured face-to-face in-depth interviews with citizens of the city of Tilburg. The interviews were conducted by students of the Tilburg University sociology programme in 2018-19. A randomly selected sample of 450 people in the age category of 18 to 80 was taken from the population register of the Tilburg municipality. The sample was stratified along five different neighbourhoods (which differ in their proportions of social assistance beneficiaries). All the potential respondents received a letter with information about the research, after which they could be contacted in person with a request to participate. The resulting sample includes 28 women and 21 men, from different age groups and with different educational backgrounds, subjective incomes and political preferences (see Appendix 2 for an overview of the interviewees and their background characteristics).

The interviews each lasted approximately one hour, and the well-trained interviewers used the same semi-structured questionnaire with questions about both a UBI and the Participation Act (the Tegenprestatie scheme). In explaining the idea of a UBI, a specific definition was presented to the respondents on paper. The definition included the following aspects: it comprises a monthly income, paid by the government, on which you can live frugally; it is the same amount for everyone, paid to all adult residents of the Netherlands; the payment is without conditions and not dependent on income, assets or work situation; it partially replaces other benefits and allowances, such as social assistance.

The interviews were transcribed and analysed through an inductive approach, without imposing a pre-defined coding scheme, to identify relevant themes that were recurrent in interviewees' words. The coding process, performed using the software Atlas.it, allowed us to define and develop these themes.

\section{Results}

After discussing how the complex topics of UBI and welfare conditionality were understood by our respondents, we present their main ideas and arguments about UBI and the Tegenprestatie. 


\section{The complexity of social policy: ambivalence and ambiguity}

With a few exceptions, the respondents did not show well-developed attitudes towards a UBI or work conditionality. Many respondents indicated that they found these topics complicated or that they had never previously thought about the questions asked. Some even indicated that it was not up to them to decide about these types of issues.

Well you know, there is not only one right answer, and if you give an answer, it is quite a complex thing. If you really start talking about it seriously then you can go in any direction. (Interviewee 15).

The following quote is a typical example of how respondents struggled with the two concepts and had difficulties in forming a clear opinion about them. Although the respondent here was in favour of the Tegenprestatie (i.e. the obligation to do something in return for receiving a benefit), she did not want to impose too many obligations. At the same time, she indicated being in favour of a UBI, but neglected the fact that it is unconditional.

I think we should keep the Tegenprestatie and obligations. There, I am actually ... you should put that in place as little as possible and I think a basic income anyway ... yes, I think you should have that, I do not think you should go below the poverty line. (Interviewee 7).

While the policy proposal of the Tegenprestatie appears to be easier to understand intuitively, a UBI seems to be a very abstract and complex social policy proposal, with many different aspects and underlying assumptions. Moreover, the idea of a UBI seemed to be largely unknown among most of our respondents. Some of them were not familiar with the concept: when asked about their knowledge of basic income, they believed it referred to the minimum wage or 'basic' household income. Moreover, quite a few respondents had difficulty in understanding the idea of a UBI, even after its different dimensions had been explained in detail by the interviewer, who provided a clear definition on paper during the interview. In general, most respondents struggled with the universalistic aspect of a UBI, as they did not understand the advantages of giving it to all citizens, given that these same citizens will pay for it through taxes. 'The basic income is simply the money you earn, what you work for' (Interviewee 11). 
Because of the complexity of social policy proposals - a UBI in particular - and the fact that many respondents were unfamiliar with a UBI, respondents started forming their opinion about these issues during the interview, often resulting in ambiguous answers or ambivalent opinions. This leads to the first conclusion regarding the reasons why qualitative research is needed when studying welfare attitudes: the findings of the quantitative surveys presented above are sometimes hard to interpret, even when a definition of the policy at issue is provided (as is the case in the ESS 2016).

\section{'Basic' income: providing a floor for the poor and making work pay}

When discussing the concept of a UBI, there is one aspect that our respondents liked in particular: the fact that they (or others) would gain more income, or more specifically that a UBI provides basic security for everyone. Although respondents often mentioned that providing every citizen with a basic income would be unaffordable or unnecessary, many nevertheless expressed enthusiasm for this feature. This is in line with Roosma and van Oorschot (2019), who concluded that people are likely to support a UBI because it provides income protection for the poor. In our interviews we find two lines of reasoning that substantiate this claim.

The first focuses on poverty relief and improving the situation for the poor, those with a low income or those dependent on (social assistance) benefits. It is argued that a UBI can provide people with basic security, which not only prevents them from falling below the poverty line, but also relieves them of the (some suggest 'humiliating') obligation to prove that they are in real need of benefits through all forms of bureaucratic rules. Basic security provides dignity. At the same time, this line of argumentation points out that people with the lowest income have difficulties making ends meet or are forced to become indebted. Many respondents considered the current level of social assistance benefit is too low, and that people are forced to live in poverty. A UBI can - or should, according to these respondents - improve the economic situation of people on a low income. It would relieve them of the stress of not having enough to pay for necessities. In addition, respondents who did not follow this line of argumentation believe that no one should fall below the poverty line and that people should be able to pay their expenses.

The person who works may be better off. But the person who does not work should not be short of anything to be able to function as an ordinary Dutch citizen. And I miss that in this country. They say it is all taken care of, but it is all just on the edge 
of it. It is too much to die of and not enough to live on. It could have been a bit more generous. (Interviewee 13).

The second line of argumentation concerns the unfairness of having similar standards of living for people on benefits and for the working population. There is a strong sense of agreement that people in low-paid jobs do not earn enough and that it is barely beneficial to work. Working often does not pay off. Respondents believed that people who work, and especially those working more hours or in more intensive jobs, should have higher incomes. Within this reasoning, the interviewees advocated the idea that working people could also receive a UBI, as their situation should be improved as well and they should be rewarded for their efforts. Some respondents who misunderstood that UBI means the same income for all - referring to it as a socialist reform in terms of 'communism' (Interviewee 43) or 'what they have in China' (Interviewee 3) - strongly rejected the idea that effort is not rewarded. However, at the same time people believe that income differences are too high. The general feeling is that the rich get richer while those on lower incomes do not progress, so there is less support for the idea of 'the rich' also benefitting from a UBI.

The lines of argument in favour of a 'basic' level of income can explain the high level of support for a UBI in some of the surveys mentioned above. Respondents might simply respond to the 'basic' in basic income, making a decent standard of living possible, and give less importance to - or remain unaware of - the aspects of unconditionality and universalism (see also: Roosma \& van Oorschot, 2019).

\section{'Basic' income, but not universal and not unconditional}

When the idea of a UBI was further discussed, our respondents articulated two main objections. First, they objected to the idea of it being provided to all citizens, regardless of their assessed financial need, arguing that it is not necessary to provide an additional income to people who have a decent income and are able to make money themselves. In this logic, a UBI potentially turns out to be an unnecessary luxury. Respondents argued that the rich or people with higher incomes (sometimes respondents referred to themselves) are not in need of benefits and therefore do not deserve support from a UBI. This relates to the above-mentioned argument that hard-working people on a low income are considered to be deserving of a higher standard of living. Only a few respondents mentioned, however, that the rich have worked for their own wealth and for that reason 
they would also be deserving of a UBI. According to this logic, it would be unfair to exclude those who have put in more effort to get ahead in society. Here, praising effort triumphs over the importance of need considerations.

I think they are all deserving, but not the very rich ones. (Interviewee 3).

Well, maybe not someone who is a millionaire, but you know, those people have probably also worked hard for their money, so yes, I think it's a shame to say, gosh they are not entitled to it. (Interviewee 11).

The second, and even stronger, objection lies in the fact that a UBI is unconditional in terms of a person's willingness to work and in their performance of work. There were very few respondents who supported this type of 'something for nothing' unconditionality (cf. left-hand extreme of Figure 1). Although they had different opinions about what should be done in return, and the reasons why people should reciprocate, it was broadly agreed that all those who are capable should do at least 'something useful in return'. It is almost considered self-evident that there should be some reciprocity in benefiting from government support. There is no such thing as a free lunch; that would be considered too easy and unrealistic. It is also considered undignified and unfair if someone puts effort into doing something in return, while others are lazy and irresponsible. Thus, even if respondents agreed with the universality aspect of a basic income, they envisioned it more as a form of participation income (Atkinson, 1996).

I find it too easy. If you want to achieve something, you have to do something for it. That's how I was raised. (Interviewee 10)

The moment you give something away without having to get anything in return, that money has no value. But if you, as is the case now, have to do something in return, however small, then it gives a sense of value. Because then it matters what you do. If it doesn't matter what you do, then one person starts applying for jobs a lot but doesn't get a job, does their utmost and gets a certain amount. While someone else who sits on their lazy backside, and does nothing, will also receive the same amount. Yes, if you look at it carefully, I don't think anyone would think that is fair. (Interviewee 43). 


\section{Work is good for everybody: prevent inactivity}

In the rejection of the unconditionality of a UBI, we find a clear link with support for the Tegenprestatie. The unconditionality aspect is an important barrier to support for a full UBI. 'Doing something in return for your benefits' was generally supported among our respondents, as has also been shown in previous quantitative work (see Appendix 1). Embedded in a strong work ethic, there is a broadly shared view that inactivity should be avoided. In principle, all those who are able should work or be supported to (get back to) work. Further, if paid work is impossible, other substitute activities should be provided by the government. However, respondents differed in their specific arguments in support of the Tegenprestatie scheme, expressed by two distinguished lines of reasoning.

The first is characterized by scepticism about people's willingness to work. Respondents believe that if people are not in some way 'forced' to work, they will prefer laziness instead of contributing to society, resulting in a culture of dependency and high unemployment. The way people should be 'forced' is by attaching strict obligations to benefit receipt. Sanctions (i.e. cutting benefits) should be prevented, but if necessary they should be applied to those who cannot be motivated in another way. Respondents following this line of reasoning believe that there are people who are really not able to work; however, they are more concerned about those who take advantage of the system. Participation is necessary, because there are many areas where additional help is needed (especially the care system) and if people are not skilled enough, they can be trained to perform specific jobs.

Of course you will always have people who can't work for medical reasons, so you shouldn't bother those people. But people who are able to work and who simply don't do anything, and think 'with this money, oh well, I don't have to do anything'... you should make them work, through mandatory voluntary work, or something similar. I think that is a condition that can be applied to it, because so many volunteers are also needed everywhere in healthcare. (Interviewee 11).

In the Netherlands it is pretty well cared for. If you can't figure it out, there is always somewhere where you can knock on the door and where you can get help. And if you refuse to do anything further with them, let's say, and do not keep your promises, there will also be a point where they can say: 'now you are on your own, find your own way'. (Interviewee 47). 
The second line of reasoning is also in favour of reciprocating for income support, but tries to 'soften' this reciprocity. In this line of reasoning, people on benefits are generally willing to participate but not always (mentally) capable of doing so. Therefore, they should be motivated in the right way to discover their talents; their unique way to contribute to society. Beneficiaries capable of doing something useful in return should, however, be able to choose - among a wide range of possibilities - the way in which they want to be active. Respondents using this line of reasoning emphasized the importance of empowerment, free choice and trust in people. Municipalities should help people to participate, especially those with disabilities, and try to find different ways to engage isolated people in social life. Sanctioning is considered neither necessary nor effective, and definitely not the right way to motivate people. Instead, the government should trust them (cf. trust experiments). In this line of reasoning, people aim to avoid humiliation and being instructed what to do by the government. Some of the obligations that are currently in place are considered unfair and too demanding. Real jobs with real wages are replaced by 'voluntary' activities of beneficiaries who fulfil their obligation to reciprocate by performing socially useful activities. According to this view, the goal of participation lies in obtaining better health and well-being for the beneficiaries. This may lead to work, but it is not the primary focus.

\footnotetext{
If people are not going to do it, then I would look at what people want to do, and why they are not doing it now. I think that would be more efficient than immediately imposing sanctions. There is always a story behind it, I think. Otherwise you will not be able to get the right approach and will be less likely to look at what really suits someone. (Interviewee 46)
}

\begin{abstract}
If there are people who may be fully capable of doing something in return, but simply do not want to because they can't be bothered, something must be done to ensure that those people do it anyway. But I think sanctions and penalties sound very harsh. That sounds like you're going to cut people's benefits .... You have to offer people opportunities, but I don't think you should impose obligations. Those possibilities may sound a little bit like obligations though. (Interviewee 8)
\end{abstract}

\title{
Feasibility: affordability and bureaucracy
}

When respondents formed their opinions about the two policy proposals presented, they generally took into account their feasibility. Whereas the radical proposal of a UBI is 
considered problematic in terms of financial feasibility, the Tegenprestatie suffers from administrative and bureaucratic feasibility issues.

The idea that a UBI would prevent poverty and improve the living conditions of those in lower socio-economic positions had broad support among our respondents. However, many doubted that a UBI is the most efficient way to reach this policy goal. Some feared that it could disadvantage those actually dependent on social benefits, as they receive potentially larger transfers under the existing systems of means-tested benefits. Others argued that it is probably much easier to increase the level of benefits and wages. Including those on middle and higher incomes seems not to be effective. Respondents further believed that a UBI is simply too costly, or that spending resources on the rich is a waste. A significant group of respondents raised the issue of financial feasibility almost immediately: they wanted to know who is going to pay for a UBI and feared it would be likely to require tax increases. Providing an additional income to people who are able to make money themselves, which is then clawed back in terms of taxes, makes a UBI an instrument that is simply 'moving cash around'. Although people were relatively positive about the fact that bureaucracy could potentially be reduced, and that the social security system would become more transparent, most respondents did not perceive a UBI as a worthy alternative to existing means-tested and contributory benefits, or as an adequate instrument for income redistribution. Most respondents generally did not see how income inequality would be reduced by a UBI.

Me too? So even if I go to work, would I also get this basic income? So I would be very well off? That sounds nice, I want to participate. Who will pay for it? (Interviewee 9).

In the end, people look at what is the bottom line, what do they get at the end of the month, and whether that is via 1000 euros unemployment benefit, or via a 1000 euros basic income, they know what they have to pay. That's how I have to make ends meet. So for me it doesn't matter much what the bottom line is. Only it might become easier or harder to get it. You need to visit fewer agencies to get to that net income. (Interviewee 47).

In the context of the Tegenprestatie, the administrative feasibility in particular was discussed. Almost all respondents mentioned being to some extent in favour of a tailormade arrangement for the Tegenprestatie. They argued that people in different 
circumstances should be treated differently and that the rules should be flexible. Civil servants should be trusted to exercise their best judgement and not follow rules to the last detail. Even those who argued that the government should draw clear lines, struggled with the fact that there are always personal reasons to provide exemptions for obligations. However, there was some doubt expressed as to whether the government or civil servants are capable of providing these tailor-made arrangements. The government was perceived as bureaucratic and inflexible and not capable of providing good guidance to those in need of a job.

Doing something in return? I don't think that is wrong. Only, you have to dare to think about tailor-made approaches. That is something we also find difficult in this country, we are very much like ... everything must be the same for everyone. (Interviewee 41).

You should not say, 'yes, but those are the rules!' No, you must look at what is ... why do you have those rules, what is the purpose? The goal is to get people to work. And as before, at that moment ... you see, okay, this rule makes no sense for this person, but actually it does make sense for another person, because it helps them positively. Yes, please omit that rule ... And that makes it so difficult, because you live in a country with so many differences. For one, this rule is relevant, and for the other, the rule is not relevant. You can't ... of course I also understand that you can't say yes, yes for you, not for you, not for you. You have to have a framework there, but if, as ... as a municipality there, as a government, you have to ensure that, yes, the rules do help. And don’t work against it. (Interviewee 43).

\section{Discussion and conclusions}

In light of the ongoing debates about the Dutch social policy system, our analysis aimed at identifying which types of arguments Dutch citizens spontaneously use to support (or oppose) a UBI and work conditionality. Our findings suggest that the arguments articulated in our in-depth interviews can be interpreted from two theoretical perspectives. First, we find that respondents make frequent use of some of the deservingness criteria recognized in relevant literature (van Oorschot et al., 2017). Deservingness theory argues that people express solidarity with those they consider to be deserving, while the undeserving are excluded from help, benefits or support. People consider five basic deservingness criteria, namely: control, attitude, reciprocity, identity and need (the so- 
called CARIN criteria, see van Oorschot, et al., 2017; Laenen, 2020). The criterion of control refers to someone's personal responsibility for getting into or out of the situation in which help or support is needed. Attitude refers to the behaviour of the potential beneficiary, who should be grateful and docile. Reciprocity entails people having to 'do something in return', which could be in the past or in the future. The identity criterion refers to how close we feel to others and to what extent we can identify with them. Lastly, the criterion of need refers to the extent to which the beneficiary is in (financial) need of support.

In our in-depth interviews, explicit references were mostly made to the deservingness criteria of control, need and reciprocity. With regard to the first, many respondents distinguished between those who are considered 'unable' to reciprocate, and those who are 'able' to get out of their situation. The latter are judged undeserving and should - to a certain extent - be 'forced' to participate. The criterion of need was mostly used by our respondents to defend their support for a UBI. They consider beneficiaries are in need of more support, as they regard the level of benefits as too low or because they want to provide the need for basic security. Many respondents felt that beneficiaries lack societal recognition and respect, as they are 'in way over their head'. This argument also includes those with 'junk jobs' or jobs that are not worthwhile and who are struggling to make ends meet. In these terms, a UBI could be a substitute for gainful employment in which citizens can find social recognition and dignity. Excluding 'the rich' from help, support or solidarity seems a logical consequence of this reasoning, as they are not needy and are already appreciated by society. The criterion of reciprocity is used to argue that a UBI violates the principle of contribution, since those who put more effort into their work should be better off than those who do not contribute through work. Respondents often indicated that people - if they are able - should do something (useful) in return. The value attached to work, the strong work ethic, can be considered as part of this argument: people cannot get 'something for nothing' and they have a duty to engage in work. In this way, support for conditionality in terms of job seeking, training and social obligations triumphs over the unconditionality of a UBI. In their strong reliance on the deservingness criteria, it seems that our respondents generally reject the idea of equal redistribution, in the sense that everybody should receive the same. In this way, they also reject an important foundation of a UBI as unconditional in terms of assessed financial need, a person's present or past contributions, and/or their willingness to work. 
While deservingness arguments relate to the characteristics of welfare recipients (e.g. their contributions, needs and work willingness), the second group of arguments refers to the characteristics of welfare schemes in terms of their administrative and financial feasibility (see also Laenen, Rossetti and van Oorschot, 2019). In the case of a UBI, most respondents seemed to agree that its implementation would be too costly; a luxury that Dutch society cannot afford. People are not very keen on the tax increases a UBI would most probably require. Some respondents even argued that it is a somewhat pointless exercise: why should we go through the administrative hassle of levying taxes on citizens, just to give it back to them in the form of a UBI? In addition, the universality of a basic income is considered problematic from an administrative and financial perspective, as spending scarce public resources on the (very) rich is seen as wasteful. With regard to the workfare-oriented Tegenprestatie scheme, the arguments revolve more around the administrative feasibility of the scheme. Even respondents who applauded the strict enforcement of work-related obligations in the welfare system often questioned its feasibility in policy practice, as it requires a hugely complex and expensive control apparatus.

To conclude, by revealing the popular arguments used by citizens, our analysis will be valuable for political actors who seek to mobilize support for (or opposition to) the real-world implementation of a UBI. In addition, the findings represent a useful starting point for future survey researchers to examine the arguments underlying opinions about a UBI and work conditionality in the broader Dutch population, as was carried out in the 1995 WOS. However, in future the answer categories could be based on the arguments raised 'bottom-up' in our in-depth interviews. Survey research could therefore benefit from the richness of the arguments given by the respondents in our study, and could use the results of our analysis to further investigate whether background characteristics - such as education level, subjective income or political affiliation influence people's arguments for supporting a UBI.

We need to bear in mind, however, that as shown by Zimmermann and colleagues in this special issue, the types of argumentation people use to defend their positions towards social policies such as a UBI are country specific. Therefore, our warning to (comparative) survey researchers is that the arguments we found should not be copied blindly, as they might be specific to the Netherlands. More qualitative research in this field is needed across multiple countries. 


\section{Notes}

1. Most of our respondents were, however, not aware of the ongoing experiment - probably because it was not reported much in Dutch popular media. Therefore, the experiment itself has had little impact on respondents' opinions and their underlying arguments.

2. CPB (1992). Nederland in drievoud: een scenariostudie van de Nederlandse economie 19902015; WRR (1981). Vernieuwingen in het arbeidsbestel; and WRR (1985). Waarborgen voor zekerheid: een nieuw stelsel van sociale zekerheid in hoofdlijnen.

3. Originally written as a collection of articles for the online journalism platform $D e$ Correspondent, it was published in English in 2016 with the title: Utopia for Realists: The Case for a Universal Basic Income, Open Borders, and a 15-hour Workweek (source: https://thecorrespondent.com/utopia-for-realists).

4. Some also argue, however, that the Dutch state pension (Algemene Ouderdomswet, $A O W$ ) can be seen as a group-targeted form of basic income, because it grants pension rights to all Dutch residents on reaching the age of 65, regardless of their work history (Groot \& van der Veen, 2000; Vanderborght, 2004). 


\section{References}

Atkinson, B. (1996). The case for a participation income. Political Quarterly, 67(1), 6770.

Bonoli, G. (2010). The political economy of active labor-market policy. Politics \& Society, 38(4), 435-457.

Bruttel, O., \& Sol, E. (2006). Work first as a European model ? Evidence from Germany and the Netherlands. Policy \& Politics, 34(1), 69-90.

Buss, C. (2018). Public opinion towards workfare policies in Europe: Polarisation of attitudes in times of austerity? International Journal of Social Welfare, 28(4), $431-441$.

Fossati, F. (2018). Who wants demanding active labour market policies? Public attitudes towards policies that put pressure on the unemployed. Journal of Social Policy, 47(1), 77-97.

Groot, L., Muffels, R., \& Verlaat, T. (2019). Welfare states' social investment strategies and the emergence of Dutch experiments on a minimum income guarantee. Social Policy \& Society, 18(2), 277-287.

Groot, L., \& van der Veen, R. (2000). How attractive is a basic income for European welfare states? In R. van der Veen \& L. Groot (Eds.), Basic income on the agenda (pp. 13-38). Amsterdam: Amsterdam University Press.

Hoogenboom, M. (2011). The Netherlands: two tiers for all. In J. Clasen \& D. Clegg (Eds.), Regulating the risk of unemployment: National adaptations to postindustrial labour markets in Europe (pp. 75-99). Oxford: Oxford University Press.

Houtman, D. (1997). Welfare state, unemployment, and social justice: Judgments on the rights and obligations of the unemployed. Social Justice Research, 10(3), 267288.

Knotz, C. (2018). Why countries 'get tough on the work-shy': The role of adverse economic conditions. Journal of Social Policy, 48(3), 615-634.

Laenen, T. (2020). Welfare deservingness and welfare policy. Popular deservingness opinions and their interaction with welfare state policies. Cheltenham: Edward Elgar Publishing. 
Laenen, T., \& Larsen, C. A. (2018). Retrenchment of unemployment protection and the absence of public resistance in Denmark and the Netherlands. The role of popular deservingness perceptions among welfare constituents. CCWS Working Papers No. 2018-93. Aalborg: Aalborg University.

Laenen, T., Rossetti, F., \& van Oorschot, W. (2019). Why deservingness theory needs qualitative research: Comparing focus group discussions on social welfare in three welfare regimes. International Journal of Comparative Sociology, 60(3), 190216.

Lodemel, I., \& Trickey, H. (2001). 'An offer you can't refuse': Workfare in international perspective. Bristol: The Policy Press.

Organisation for Economic Co-operation and Development (OECD, 2017) Basic income as a policy option: Can it add up? Policy brief on the future of work. Paris: OECD.

Roosma, F., \& Jeene, M. (2017). The deservingness logic applied to public opinions concerning work obligations for benefit claimants. In W. van Oorschot, B. Meuleman, T. Reeskens, \& F. Roosma (Eds.), The social legitimacy of targeted welfare: attitudes to welfare deservingness (pp. 189-205). Cheltenham: Edward Elgar Publishing.

Roosma, F., \& van Oorschot, W. (2019). Public opinion on basic income: Mapping European support for a radical alternative for welfare provision. Journal of European Social Policy. Advance online publication. https://doi.org/10.1177/0958928719882827

van der Veen, R. (2019). Basic income experiments in the Netherlands? Basic Income Studies, 1-13.

van Oorschot, W. (1998). Dutch public opinion on social security. A descriptive summary of survey results. Loughborough: Centre for Research in Social Policy, Loughborough University.

van Oorschot, W., \& Engelfriet, R. (1999). Work, work, work: labour market participation policies in the Netherlands 1970-2000. East-West Review of Social Policy, 4(2), 149-192.

van Oorschot, W., Roosma, F., Meuleman, B., \& Reeskens, T. (Eds.). (2017). The social legitimacy of targeted welfare: Attitudes to welfare deservingness. Cheltenham: Edward Elgar Publishing.

van Parijs, P. (2004). Basic income: A simple and powerful idea for the twenty-first century. Politics \& Society, 32(1), 7-39. 
Vanderborght, Y. (2004). Universal basic income in Belgium and the Netherlands: Implementation through the back door? EUI Working Paper SPS No. 2004/4. Florence: European University Institute.

Vrooman, J. C., \& De Kemp, A. A. M. (1995). Andere zekerheden - ministelsel, basisinkomen en participatiemodel onderzocht. Openbare Uitgaven, 27(2), 7485.

Watts, B., \& Fitzpatrick, S. (2018). Welfare conditionality. New York: Routledge.

Widerquist, K. (2018). A critical analysis of basic income experiments for researchers, policymakers, and citizens. Cham: Palgrave Macmillan. 
Appendix 1. Public support for UBI and work-related conditionality in the Netherlands, 1993 - 2016.

\begin{tabular}{|c|c|c|c|c|c|c|}
\hline Data source & Support for UBI & & & Support for work-related conditionality & & \\
\hline $\begin{array}{l}\text { Social and } \\
\text { Cultural } \\
\text { Planning } \\
\text { Bureau (1993) }\end{array}$ & $\begin{array}{l}\text { In the newspapers and on television, there is talk } \\
\text { of the implementation of a basic income. This } \\
\text { means that in the future all working and non- } \\
\text { working individuals receive a fixed amount (of } \\
600 \text { Dutch guilder per month) from the } \\
\text { government. Someone without work is not } \\
\text { obliged to search for a paid job, and because of } \\
\text { the basic income many of the existing social } \\
\text { security schemes can be abolished. }\end{array}$ & $\begin{array}{l}\text { (strongly) in } \\
\text { favour }\end{array}$ & $19.0 \%$ & $\begin{array}{l}\text { Another possibility is that all Dutch adults } \\
\text { younger than } 65 \text { are forced to work. Someone } \\
\text { who is unemployed or disabled and cannot find } \\
\text { a job on its own will get a job from the } \\
\text { government in which he or she performs work } \\
\text { that is useful for society. In return, he or she } \\
\text { receives the minimum wage. People who refuse } \\
\text { the job offer, do not get any benefits from the } \\
\text { government. Only severely sick people are not } \\
\text { forced to work. }\end{array}$ & $\begin{array}{l}\text { (strongly) } \\
\text { favour }\end{array}$ & $59.0 \%$ \\
\hline $\begin{array}{l}\text { Welfare } \\
\text { Opinions } \\
\text { Survey (1995) }\end{array}$ & $\begin{array}{l}\text { In the newspapers and on television there is talk } \\
\text { of the implementation of a basic income. This } \\
\text { means that in the future all Dutch people, } \\
\text { workers and non-workers, will receive a fixed } \\
\text { amount from the government, which is just } \\
\text { enough to get by. Those who work complement } \\
\text { this amount with a salary. Those who do not } \\
\text { work are not obliged to search for paid work. } \\
\text { Because of the basic income many of the } \\
\text { existing social security schemes will become } \\
\text { obsolete. }\end{array}$ & $\begin{array}{ll}\text { (strongly) } & \text { in } \\
\text { favour } & \\
\text { no } & \text { opinion } \\
\text { (strongly) } & \text { against }\end{array}$ & $\begin{array}{l}19.1 \% \\
31.0 \% \\
49.9 \%\end{array}$ & $\begin{array}{l}\text { Another possibility is that all Dutch adults } \\
\text { younger than } 65 \text { are forced to work. Someone } \\
\text { who is unemployed or disabled and cannot find } \\
\text { a job on its own will get a job from the } \\
\text { government in which he or she performs work } \\
\text { that is useful for society. In return, he or she } \\
\text { receives the minimum wage. People who refuse } \\
\text { the job offer, do not get any benefits from the } \\
\text { government. Only severely sick people are not } \\
\text { forced to work. }\end{array}$ & $\begin{array}{l}\text { (strongly) in } \\
\text { favour } \\
\text { no } \quad \text { opinion } \\
\text { strongly against }\end{array}$ & $\begin{array}{l}55.7 \% \\
20.4 \% \\
23.9 \%\end{array}$ \\
\hline
\end{tabular}




\begin{tabular}{|c|c|c|c|c|c|c|}
\hline $\begin{array}{l}\text { Eurobarometer } \\
56.1(2001)\end{array}$ & $\begin{array}{l}\text { The government should provide everyone with a } \\
\text { guaranteed basic income. }\end{array}$ & $\begin{array}{l}\text { (strongly) agree } \\
\text { neither agree, nor } \\
\text { disagree } \\
\text { (strongly) } \\
\text { disagree }\end{array}$ & $\begin{array}{l}14.7 \% \\
15.1 \%\end{array}$ & $\begin{array}{l}\text { The unemployed should be forced to take a job } \\
\text { quickly, even if it is not as good as their previous } \\
\text { job. }\end{array}$ & $\begin{array}{l}\text { (strongly) agree } \\
\text { neither agree, nor } \\
\text { disagree } \\
\text { (strongly) } \\
\text { disagree }\end{array}$ & $\begin{array}{l}8.8 \% \\
9.5 \%\end{array}$ \\
\hline $\begin{array}{l}\text { European } \\
\text { Social Survey } \\
(2016)\end{array}$ & $\begin{array}{l}\text { Some countries are currently talking about } \\
\text { introducing a basic income scheme. A basic } \\
\text { income scheme includes all of the following: (1) } \\
\text { the government pays everyone a monthly } \\
\text { income to cover essential living costs; (2) it } \\
\text { replaces many other social benefits; (3) the } \\
\text { purpose is to guarantee everyone a minimum } \\
\text { standard of living; (4) everyone receives the } \\
\text { same amount regardless of whether or not they } \\
\text { are working; (5) people also keep the money } \\
\text { they earn from work or other sources; and (6) } \\
\text { this scheme is paid for by taxes. }\end{array}$ & $\begin{array}{l}\text { (strongly) in } \\
\text { favour } \\
\text { no opinion } \\
\text { (strongly) against }\end{array}$ & $\begin{array}{l}46.7 \% \\
4.9 \% \\
48.4 \%\end{array}$ & $\begin{array}{l}\text { Imagine someone who is unemployed and } \\
\text { looking for work. This person was previously } \\
\text { working but lost their job and is now receiving } \\
\text { unemployment benefit. What should happen to a } \\
\text { person's unemployment benefit (UB) if this } \\
\text { person turns down a job because it pays a lot less } \\
\text { than what they earned previously? }\end{array}$ & $\begin{array}{l}\text { lose all UB } \\
\text { lose about half of } \\
\text { UB } \\
\text { lose } \\
\text { UB } \\
\text { kell part of } \\
\text { keep all }\end{array}$ & $\begin{array}{l}16.1 \% \\
21.6 \% \\
45.0 \% \\
17.3 \%\end{array}$ \\
\hline
\end{tabular}


Appendix 2. Overview of respondents' characteristics.

\begin{tabular}{|c|c|c|c|c|c|c|c|}
\hline $\begin{array}{l}\text { Interviewee } \\
\text { ID }\end{array}$ & $\begin{array}{l}\text { Year of } \\
\text { Interview }\end{array}$ & Neighbourhood & Age & Gender & $\begin{array}{l}\text { Political } \\
\text { left-right } \\
\text { self- } \\
\text { placement } \\
(0-10)^{*}\end{array}$ & $\begin{array}{l}\text { Subjective } \\
\text { income } \\
\text { cat. })^{* *}\end{array}$ & $\begin{array}{l}\text { Education } \\
(3 \text { cat.)*** }\end{array}$ \\
\hline 1 & 2018 & De Blaak & 66 & Male & 6 & Enough & High \\
\hline 2 & 2018 & De Blaak & 39 & Female & 7 & Enough & High (univ) \\
\hline 3 & 2018 & De Blaak & 65 & Female & 5 & $\begin{array}{l}\text { More than } \\
\text { enough }\end{array}$ & High \\
\hline 4 & 2018 & $\begin{array}{l}\text { Wandelbos } \\
\text { Noord }\end{array}$ & 44 & Female & 4 & Enough & High \\
\hline 5 & 2018 & $\begin{array}{l}\text { Wandelbos } \\
\text { Noord }\end{array}$ & 45 & Female & 3 & Not enough & Low \\
\hline 6 & 2018 & $\begin{array}{l}\text { Wandelbos } \\
\text { Noord }\end{array}$ & 56 & Female & 6 & Just enough & Middle \\
\hline 7 & 2018 & Bouwmeester & 25 & Male & 4 & $\begin{array}{l}\text { More than } \\
\text { enough }\end{array}$ & Middle \\
\hline 8 & 2018 & Bouwmeester & 23 & Female & 4 & Just enough & Middle \\
\hline 9 & 2018 & $\begin{array}{l}\text { Wandelbos } \\
\text { Noord }\end{array}$ & 56 & Male & 5 & $\begin{array}{l}\text { More than } \\
\text { enough }\end{array}$ & Middle \\
\hline 10 & 2018 & $\begin{array}{l}\text { Wandelbos } \\
\text { Noord }\end{array}$ & 41 & Male & 7 & Enough & Middle \\
\hline \begin{tabular}{|l|}
11 \\
\end{tabular} & 2018 & $\begin{array}{l}\text { Wandelbos } \\
\text { Noord }\end{array}$ & 37 & Female & 7 & $\begin{array}{l}\text { More than } \\
\text { enough }\end{array}$ & High \\
\hline 12 & 2018 & $\begin{array}{l}\text { Wandelbos } \\
\text { Noord }\end{array}$ & 50 & Male & 6 & $\begin{array}{l}\text { More than } \\
\text { enough }\end{array}$ & Low \\
\hline 13 & 2018 & $\begin{array}{l}\text { Wandelbos } \\
\text { Noord }\end{array}$ & 56 & Male & 5 & Not enough & Middle \\
\hline 14 & 2018 & $\begin{array}{l}\text { Wandelbos } \\
\text { Noord }\end{array}$ & 70 & Female & 5 & Enough & Low \\
\hline 15 & 2018 & $\begin{array}{l}\text { Wandelbos } \\
\text { Noord }\end{array}$ & 32 & Male & 4 & $\begin{array}{l}\text { More than } \\
\text { enough }\end{array}$ & Middle \\
\hline 16 & 2018 & $\begin{array}{l}\text { Wandelbos } \\
\text { Noord }\end{array}$ & 59 & Male & 5 & $\begin{array}{l}\text { More than } \\
\text { enough }\end{array}$ & Low \\
\hline \begin{tabular}{|l|}
17 \\
\end{tabular} & 2018 & $\begin{array}{l}\text { Wandelbos } \\
\text { Noord }\end{array}$ & 67 & Male & 5 & $\begin{array}{l}\text { More than } \\
\text { enough }\end{array}$ & Middle \\
\hline
\end{tabular}




\begin{tabular}{|c|c|c|c|c|c|c|c|}
\hline 18 & 2018 & $\begin{array}{l}\text { Wandelbos } \\
\text { Noord }\end{array}$ & 48 & Male & 4 & Just enough & High (univ) \\
\hline 19 & 2018 & $\begin{array}{l}\text { Wandelbos } \\
\text { Noord }\end{array}$ & 74 & Female & 5 & $\begin{array}{ll}\text { Refuse } & \text { to } \\
\text { answer } & \end{array}$ & Middle \\
\hline 20 & 2018 & $\begin{array}{l}\text { Wandelbos } \\
\text { Noord }\end{array}$ & 78 & Female & 5 & Enough & Middle \\
\hline 21 & 2018 & De Blaak & 51 & Female & 5 & Just enough & High \\
\hline 22 & 2018 & De Blaak & 55 & Female & 5 & $\begin{array}{l}\text { More than } \\
\text { enough }\end{array}$ & Middle \\
\hline 23 & 2018 & De Blaak & 68 & Male & 4 & $\begin{array}{l}\text { More than } \\
\text { enough }\end{array}$ & High \\
\hline 24 & 2018 & De Blaak & 64 & Male & 4 & Enough & High (univ) \\
\hline 25 & 2018 & De Blaak & 35 & Female & 3 & Just enough & Middle \\
\hline 26 & 2018 & De Blaak & 68 & Female & 5 & $\begin{array}{l}\text { More than } \\
\text { enough }\end{array}$ & High \\
\hline 27 & 2018 & Bouwmeester & 54 & Female & 5 & $\begin{array}{l}\text { More than } \\
\text { enough }\end{array}$ & Low \\
\hline 28 & 2018 & Bouwmeester & 39 & Female & 3 & Enough & High \\
\hline 29 & 2018 & Bouwmeester & 63 & Female & 2 & Just enough & Middle \\
\hline 30 & 2018 & Bouwmeester & 57 & Female & $\begin{array}{l}\text { Don't } \\
\text { know }\end{array}$ & $\begin{array}{l}\text { More than } \\
\text { enough }\end{array}$ & Middle \\
\hline 31 & 2018 & Bouwmeester & 53 & Female & 7 & $\begin{array}{l}\text { More than } \\
\text { enough }\end{array}$ & Middle \\
\hline 32 & 2018 & De Blaak & 53 & Male & NA & NA & NA \\
\hline 33 & 2018 & De Blaak & 64 & Female & NA & NA & NA \\
\hline 34 & 2018 & De Blaak & 76 & Female & NA & NA & NA \\
\hline 35 & 2018 & Bouwmeester & 63 & Female & 5 & $\begin{array}{l}\text { More than } \\
\text { enough }\end{array}$ & High (univ) \\
\hline 36 & 2018 & Bouwmeester & 48 & Male & 7 & $\begin{array}{l}\text { More than } \\
\text { enough }\end{array}$ & Middle \\
\hline 37 & 2018 & Bouwmeester & 68 & Female & 3 & $\begin{array}{l}\text { More than } \\
\text { enough }\end{array}$ & Middle \\
\hline 38 & 2019 & Jeruzalem & 59 & Female & 2 & $\begin{array}{l}\text { More than } \\
\text { enough }\end{array}$ & High \\
\hline 39 & 2019 & Jeruzalem & 39 & Female & 3 & Enough & High (univ) \\
\hline 40 & 2019 & Jeruzalem & 64 & Male & 3 & $\begin{array}{l}\text { More than } \\
\text { enough }\end{array}$ & High (univ) \\
\hline 41 & 2019 & Tivoli & 68 & Male & 1 & $\begin{array}{l}\text { More than } \\
\text { enough }\end{array}$ & High (univ) \\
\hline
\end{tabular}




\begin{tabular}{|l|l|l|l|l|l|l|l|}
\hline 42 & 2019 & Tivoli & 55 & Male & 4 & $\begin{array}{l}\text { More than } \\
\text { enough }\end{array}$ & High \\
\hline 43 & 2019 & Tivoli & 40 & Male & 5 & Enough & High \\
\hline 44 & 2019 & Tivoli & 39 & Male & 7 & $\begin{array}{l}\text { More than } \\
\text { enough }\end{array}$ & High (univ) \\
\hline 45 & 2019 & Tivoli & 63 & Female & NA & NA & NA \\
\hline 46 & 2019 & Tivoli & 56 & Female & 3 & $\begin{array}{l}\text { More than } \\
\text { enough }\end{array}$ & High (univ) \\
\hline 47 & 2019 & Jeruzalem & 41 & Male & 7 & Enough & High \\
\hline 48 & 2019 & Jeruzalem & 31 & Male & 7 & $\begin{array}{l}\text { More than } \\
\text { enough }\end{array}$ & High (univ) \\
\hline 49 & 2019 & Jeruzalem & 50 & Female & 4 & Enough & High \\
\hline
\end{tabular}

Background characteristics questions were surveyed at the end of the interview and were stated as follows:

* Political affiliation: We would like to know what your political position is. On a scale from 0 to 10 , where 0 is far left and 10 is far right: where would you place yourself?

** Subjective income: Which of the following statements best describes your current situation, taking into account the total income you currently have? We have / I have 1) More than enough, we can easily save; 2) Enough and live without difficulties; 3) Just enough to make ends meet; 4) Not have enough and regularly have difficulties to make ends meet

*** Education: What is your highest completed education? The answers were categorized in three categories: 1) Lower education (primary education, lower vocational education, high school - middle level) 2) Middle level education (high school - higher level, secondary vocational education), 3) Higher level education (higher professional education and university education (separately indicated)). 